JOSETA: Journal of Socio Economic on Tripical Agriculture Volume 1 Nomor 2: 99 - 109 Agustus (2019)

JOSETA: Journal of Socio Economic on Tropical Agriculture http://joseta.faperta.unand.ac.id

ISSN : 2686 - 0953

\title{
Alokasi Jam Kerja Dan Pendapatan Buruh Tani Perempuan Di Pt Anam Koto Kecamatan Pasaman Kabupaten Pasaman Barat
}

\section{Allocation Of Work Hours And Work Income In Women In PT Anam Koto Kecamatan Pasaman Kabupaten Pasaman Barat Yozi Rahmayani ${ }^{1}$, Dwi Evaliza ${ }^{2}$, Zulvera ${ }^{3}$}

\author{
${ }^{1}$ Mahasiswa Program Studi Agribisnis Fakultas Pertanian Universitas Andalas, Padang \\ ${ }^{2}$ Staff Pengajar Program Studi Agribisnis Fakultas Pertanian Universitas Andalas, Padang \\ ${ }^{3}$ Staff Pengajar Program Studi Agribisnis Fakultas Pertanian Universitas Andalas, Padang \\ E-mail Korespondensi: yozi.rahmayani.yr@gmai.com
}

\begin{abstract}
Abstrak
Penelitian ini bertujuan untuk menganalisis (1) untuk mendeskripsikan karakteristik dan pola kerja buruh tani perempuan yang bekerja di PT Anam Koto Kecamatan Pasaman, Kabupaten Pasaman Barat. (2) Menghitung alokasi waktu kerja dan pendapatan buruh tani perempuan yang bekerja di PT Anam Koto Kecamatan Pasaman, Kabupaten Pasaman Barat.Penelitian ini dilakukan pada tanggal 1-30 Januari 2019. Data yang digunakan dalam penelitian ini adalah data primer. Metode yang digunakan adalah metode survei yang menggunakan kuisioner sebagai instrumen pengumpulan data. Metode pengambilan sampel yang digunakan adalah simple random sampling. Data dianalisis untuk tujuan pertama dengan deskriptif kualitatif, untuk tujuan kedua dianalisis dengan analisis kuantitaif. Hasil analisis menunjukkan bahwa (1) Profil buruh tani perempuan yang bekerja di PT Anam Koto , rata-rata buruh tani perempuan memiliki usia yang produktif untuk bekerja, namun tidak memiliki latar belakang pendidikan yang tinggi, memiliki jumlah anggota keluarga paling banyak kisaran 2-4 orang dan jumlah tanggungan keluarga paling banyak kisaran 13 orang dan lama bekerja di PT Anam Koto 1-2 tahun. Pola kerja buruh tani perempuan yang bekerja di PT Anam Koto yaitu mereka bekerja melakukan pemeliharaan kelapa sawit, pemupukan dan mengumpulkan brondolan kelapa sawit. Buruh tani perempuan bekerja enam hari selama satu minggu yaitu dari hari senin hingga sabtu, dan mempunyai hari libur yaitu hari minggu. Buruh tani perempuan yang bekerja di PT Anam Koto ada yang tinggal di barak tempat hunian para buruh yang telah di sediakan PT Anam Koto dan ada juga yang tinggal di rumah miliknya sendiri di luar lokasi PT Anam Koto. (2) Pendapatan buruh tani perempuan yang bekerja di PT Anam Koto selama satu bulan dengan pendapatan paling banyak didapatkan oleh responden yaitu rentang Rp 500.000 sampai Rp 1.000.000 sebanyak 24 responden atau sebesar $80 \%$. Jumlah jam kerja rata-rata/individu yang dilakukan oleh buruh tani perempuan di PT Anam Koto pada setiap kegiatan memiliki perbedaan pada alokasi jam kerjanya. Pada kegiatan pengutipan brondol adalah kegiatan yang mempunyai waktu paling banyak dengan jumlah alokasi jam kerja/individu selama satu bulan yang dilakukan oleh buruh tani perempuan yaitu sebesar $32 \mathrm{jam} / \mathrm{bulan}$.
\end{abstract}

Kata Kunci : Jam Kerja, Pendapatan, dan Buruh Tani Perempuan

\section{Abstrak}

The research aims to analyze (1) To describe the characteristics and patterns of work of female farm laborers who work in PT Anam Koto, Pasaman District, West Pasaman Regency. (2) Calculating the work time allocation and income of female farm laborers who work in PT Anam Koto Pasaman District, West Pasaman Regency. This study was conducted on 1-30 January 2019. The data used in this study were primary data. The method used is a survey method that uses questionnaires as an instrument for data collection. The sampling method used is simple random sampling. Data were 
analyzed for the first purpose with descriptive qualitative, for the second purpose analyzed by quantitative analysis. The results of the analysis show that (1) The profile of female farm laborers working at PT Anam Koto, the average female farm laborer has a productive age to work, but does not have a high education background, having the most family members in the range of 2-4 people and the number of dependents at most ranges from 1-3 people and work long at PT Anam Koto 1-2 years. The working pattern of female farm laborers working at PT Anam Koto is that they work to maintain oil palm, fertilize and collect palm oil waste. Female farm workers work six days a week, from Monday to Saturday, and have holidays, namely Sundays. There are female farm workers working at PT Anam Koto who live in the barracks of workers' homes that have been provided by PT Anam Koto and there are also those who live in their own homes outside the PT Anam Koto location. (2) The income of female farm laborers working at PT Anam Koto for one month with the most income obtained by respondents is the range of Rp. 500,000 to Rp. 1,000,000 for 24 respondents or $80 \%$. The number of average / individual working hours carried out by female farm workers at PT Anam Koto at each activity differs from the allocation of working hours. In the activity of brondol quotation, it is an activity that has the most time with the number of work / individual hours allocated for one month by female farm workers, which is 32 hours / month.

Keywords : working hours, Income, female farm laborers

\section{PENDAHULUAN}

Negara Indonesia terkenal sebagai negara agraris. Para petani di Indonesiia pada umumnya telah melakukan kegiatan usahatani dalam berbagai bentuk komuditi usaha, mulai dari bidang pertanian, perkebunan, perikanan serta bidang peternakan. Hal ini dilakukan terutama untuk menambah pendapatan petani, memanfaatkan lahan yang tersedia serta untuk saling mengisi dalam kegiatan usahataninya (Atiqoh , 2012:1)

Kelapa sawit merupakan salah satu komoditas hasil perkebunan yang mempunyai peranan cukup penting dalam kegiatan perekonomian di Indonesia. Kelapa sawit juga salah satu komoditas ekspor Indonesia yang cukup penting sebagai penghasil devisa negara selain minyak dan gas. Indonesia merupakan negara produsen dan eksportir kelapa sawit terbesar dunia (BPS, $2017: 3$ ).

Perkebunan harus didukung oleh faktor produksi yang dikategorikan atas modal, tenaga kerja, sumber daya alam dan kewirausahaan. Tenaga kerja merupakan faktor produksi yang secara langsung maupun tidak langsung dalam pelaksanaan produksi. Namun, dalam perkebunan jelas terlihat bahwa tenaga kerja menjadi faktor penting karena dalam prosesnya perkebunan tidak mengandalkan teknologi tinggi melainkan tenaga kerja yang terutama terjun langsung ke lapangan (Nati, $2012: 1$ )

PT Anam Koto merupakan perusahaan yang bergerak dalam bidang industri pabrik dan perkebunan kelapa sawit. PT Anam Koto terletak di Kecamatan Pasaman Kabupaten Pasaman Barat. PT Anam Koto memiliki tenaga kerja sebanyak 788 orang, dengan tenaga kerja laki-laki berjumlah 551 orang dan tenaga kerja perempuan berjumlah 237 orang.

Tersedianya PT Anam Koto Kecamatan Pasaman, Kabupaten Pasaman Barat memberikan peluang kerja bagi buruh tani di PT Anam Koto tersebut . Buruh tani tidak hanya melibatkan kaum laki-laki, tetapi juga banyak melibatkan kaum perempuan sebagai pekerja. Bagi perempuan yang memiliki pendidikan dan kreatifitas yang masih rendah menjadikan pekerjaan buruh tani sebagai pilihan mereka karena pekerjaan buruh tani merupakan pekerjaan yang tidak membutuhkan keahlian khusus.

Perempuan dalam hal ini adalah buruh tani harian lepas yang bekerja di PT Anam Koto. Kegiatan yang biasa dilakukan oleh buruh tani perempuan seperti halnya melakukan kegiatan pemeliharaan, pemupukan, dan pasca panen pada perkebunan kelapa sawit. Dengan adanya waktu kerja mereka yang jika dilihat menghabiskan waktu 1 hari, maka dirasa perlu mengkaji alokasi waktu kerja dan pendapatan buruh tani perempuan yang bekerja di PT Anam Koto. Hal ini menjadi sangat menarik bagi peneliti untuk dapat melihat bagaimana alokasi waktu kerja dan pendapatan buruh tani perempuan yang bekerja di PT 
Anam Koto Kecamatan Pasaman, Kabupaten Pasaman Barat. Oleh karena itu penelitian ini mengambil judul Alokasi Jam Kerja dan Pendapatan Buruh Tani di PT Anam Koto Kecamatan Pasaman, Kabupaten Pasaman Barat.

Berdasarkan rumusan masalah di atas, maka timbullah pertayaan berikut

1. Bagaimana karakteristik dan pola kerja buruh tani perempuan yang bekerja di PT Anam Koto Kecamatan Pasaman, Kabupaten Pasaman Barat?

2. Bagaimana alokasi jam kerja dan pendapatan buruh tani perempuan di PT. Anam Koto Kecamatan Pasaman Kabupaten Pasaman?

\section{METODE PENELITIAN}

Penelitian ini dilaksanakan di PT Anam Koto Kecamatan Pasaman, Kabupaten Pasaman Barat. Pemilihan lokasi penelitian ini dilakukan secara sengaja (purposive). Metode yang digunakan dalam penelitian ini adalah mentode survei yang menggunakan kuisioner sebagai instrumen dalam pengumpulan data. Teknik yang digunakan dalam untuk menentukan sampel dalam penelitian ini adalah teknik simple random sampling. Untuk tujuan pertama, yaitu mendeskripsikan karakteristik dan pola kerja buruh tani perempuan yang bekerja di PT Anam Koto, maka variabel yang diamati adalah:

1. Umur

2. Tingkat pendidikan

3. Jumlah anggota keluarga

4. Lama bekerja di PT Anam Koto

Untuk tujuan kedua, yaitu untuk mengetahui bagaimana alokasi jam kerja dan pendapatan buruh tani perempuan di PT Anam koto maka variabel yang diamati yaitu waktu yang dialokasikan buruh tani perempuan berdasarkan kegiatan yang dilakukan dalam bekerja di PT Anam Koto. Seperti pada kegiatan semprot piringan pasar pikul, semprot gawangan, oles anak kayu, babat gawangan, pemupukan, dan pengutipan brondol. Untuk mengetahui alokasi jam kerja buruh tani perempuan yang bekerja di PT Anam Koto yaitu dengan menghitung jam kerja pada setiap kegiatan pekerjaan yang dilakukan dan dikonversikan dalam waktu satu bulan.

Untuk mengetahui pendapatan buruh tani perempuan yang bekerja di PT Anam Koto , variabel yang diamati yaitu pendapatan buruh tani perempuan yang dilihat dalam 1 bulan yaitu bulan Januari 2019, dengan menghitung penerimaan dikurangi biaya yang dikeluarkan saat bekerja di PT Anam Koto.

Untuk tujuan pertama, maka dilakukan analisis deskriptif kualitatif. Deskriptif kualitatif adalah menganalisis, menggambarkan, dan meringkas berbagai kondisi, situasi dan berbagai data yang dikumpulkan berupa hasil wawancara atau pengamatan mengenai masalah yang terjadi di lapangan ( I Made Minartha 2006 : 155) .Tujuan pertama yaitu mendeskripsikan karakterisik dan pola kerja buruh tani perempuan yang bekerja di PT Anam Koto, dilakukan dengan wawancara langsung kepada buruh tani perempuan. Wawancara ini dilakukan dengan menanyakan langsung pertanyaan yang dibutuhkan untuk menganalisis data. Sebelum melakukan wawancara langsung, peneliti sudah menyiapkan dulu kuisioner.

Untuk tujuan kedua, digunakan analisis kuantitatif berdasarkan data yang diperoleh selama satu bulan yaitu melihat responden mengalokasikan jam kerja dan pendapatan, data yang dianalisis adalah alokasi waktu yang dilakukan oleh buruh tani perempuan di PT Anam Koto. Dan untuk pendapatan yaitu dengan menghitung penerimaan dikurangi biaya yang dikeluarkan saat bekerja di PT Anam Koto. 


\section{HASIL DAN PEMBAHASAN}

\section{A. Gambaran Umum PT Anam Koto}

PT Anam Koto adalah sebuah perusahaan yang bergerak di bidang perkebunan. PT Anam Koto beralamat di Jorong Labuh Lurus Nagari Aia Gadang Kecamatan Pasaman Kabupaten Pasaman Barat. PT Anam koto berdiri pada tahun 1993 dengan pemilik pertama Rahman Bin Akad orang Malaysia dan Manajernya bernama Irwan Roza. Setelah melewati proses yang panjang dan peralihan ke pengusaha Indonesia, saat ini pemilik PT Anam Koto adalah Buyung Tan dan Manajernya adalah Herry Sustanto. PT Anam koto memiliki luas $4740 \mathrm{Ha}$ dengan sertifkat HGU (Hak Guna Usaha) dan telah menghasilkan produksi TBS (Tandan Buah Segar) sebanyak 7.600 ton/bulan. PT Anam Koto Grup terdiri dari beberapa perusahaan, di antaranya yaitu PT Sari Buah Sawit, Sawita Pasaman Jawa, Buana Citra Andalas, Riau Sawit Mandiri, Dharmasraya Sawit Lestari. Kantor pusat PT Anam Koto beralamat di Sona Topas Tower Lantai 5a Jl. Jedral Sudirman No. 26 Jakarta 12920. PT Anam Koto memiliki sertifikat ISPO (Indonesian Sustainable Palm Oil).

Untuk mendukung tujuan perusahaan, maka Visi dari perusahaan PT Anam Koto adalah : "Menjadi korporasi agrobisnis kelapa sawit yang diakui di Indonesia yang menguntungkan dengan pengelolaan terbaik, terintegrasi dan berkesinambungan". Sedangkan Misi nya adalah : "(1) Mensejahterakan masyarakat sekitar pada umumnya dan mensejahterakan karyawan pada khususnya, (2) Meningkatkan kesadaran akan pentingnya memproduksi minyak sawit lestari, (3) Meningkatkan nilai moral dan spiritual karyawan, (4) Menjadikan karyawan sebagai asset perusahaan, (5) Meningkatkan kompetensi sumberdaya manusia secara berkesinambungan melalui pelatihan yang relevan dibidangnya masing-masing sehingga setiap individu menjadi profesional dan zero accident dalam pekerjaannya, (6) Peningkatan pengelolaan limbah dan lingkungan, keselamatan dan kesehatan kerja, dan menghemat energy melalui pengembangan teknologi, dan (7) Menerapkan system manajemen yang terbaik pada semua proses bisnis perusahaan".

\section{B. Karakteristik Buruh Tani Perempuan yang Bekerja di PT Anam Koto}

Berdasarkan data yang telah diperoleh, maka dapat dikemukakan karakteristik buruh tani perempuan yang bekerja di PT Anam Koto meliputi, umur, pendidikan terakhir, jumlah anggota keluarga, dan pengalaman kerja/lama bekerja di PT Anam Koto. Untuk lebih jelasnya terkait karakteristik buruh tani perempuan, maka dapat dilihat pada Tabel. 1

Tabel 1. Karakteristik Buruh Tani Perempuan yang Bekerja di PT Anam Koto

\begin{tabular}{|c|c|c|c|}
\hline No & Kriteria & $\begin{array}{l}\text { Jumlah } \\
\text { (orang) }\end{array}$ & $\begin{array}{c}\text { Persentase } \\
(\%)\end{array}$ \\
\hline 1 & Umur (Tahun) & & \\
\hline & a. $21-30$ & 16 & 53,3 \\
\hline & b. $31-40$ & 8 & 26,7 \\
\hline & c. $41-50$ & 4 & 13,3 \\
\hline & d. $51-60$ & 2 & 6,7 \\
\hline 2 & Pendidikan Terakhir & & \\
\hline & a. Tidak Sekolah & 7 & 23,3 \\
\hline & b. SD & 15 & 50 \\
\hline & c. SMP & 6 & 20 \\
\hline & d. SMA & 2 & 6,7 \\
\hline 3 & Jumlah Anggota Keluarga (Orang). & & \\
\hline
\end{tabular}




\begin{tabular}{|c|c|c|c|}
\hline & a. $2-4$ & 16 & $\overline{53,3}$ \\
\hline & b. $5-7$ & 12 & 40 \\
\hline & c. $>7$ & 2 & 6,7 \\
\hline 4 & $\begin{array}{l}\begin{array}{l}\text { Lama Bekerja di PT Anam Koto } \\
\text { (Tahun) }\end{array} \\
\end{array}$ & & \\
\hline & a. $<1$ & 4 & 13,3 \\
\hline & b. $1-2$ & 14 & 46.7 \\
\hline & c. $3-4$ & 12 & 40 \\
\hline
\end{tabular}

Dari Tabel.1 dapat terlihat buruh tani perempuan yang berumur 21 hingga 30 tahun sebanyak 16 responden dengan persentase sebesar 53,3\%, buruh tani perempuan yang berumur 31 hingga 40 tahun sebanyak 8 responden dengan persentase sebesar 26,7\%, buruh tani perempuan yang berumur 41 hingga 50 tahun sebanyak 4 responden dengan persentase sebesar 13,3\% dan buruh tani perempuan yang berumur 51 hingga 60 tahun sebanyak 2 responden dengan persentase sebesar 6,7\%. Komposisi umur tersebut menunjukkan bahwa buruh tani perempuan yang bekerja di PT Anam Koto adalah buruh tani yang masih kuat dalam bekerja. Para buruh tani perempuan ini masih berada pada usia produktif. Hal ini menunjukkan bahwa secara fisik dan mental sebagain besar buruh tani perempuan ini memiliki kemampuan yang cukup optimal dalam bekerja. Menurut Suroto dalam Mulyadi (2014:33) umur merupakan fakor yang berperan penting dalam menentukan produktivitas tenaga kerja. Semakin bertambah umur seseorang, produktivitasnya dapat meningkat seiring dengan bertambahnya pengalaman bekerja atau masa kerja, tetapi pada suatu saat penambahan umur ini justru akan menurunkan produktivitas tenaga kerja seiring dengan kemampuan fisik yang semakin menurun pula.

Pada tingkat pendidikan buruh tani perempuan yang Tidak Bersekolah sebanyak 7 responden dengan persentase sebesar 23,3\%, sedangkan tamatan SD sebanyak 15 responden dengan persentase sebesar 50\%, untuk SMP/STLP/Sederajat sebanyak 6 responden dengan persentase sebesar 20\%, sedangkan untuk SMA/SLTA/Sederajat sebanyak 2 responden dengan persentase sebesar $6,7 \%$. Dari hasil data yang diperoleh pada tingkat pendidikan buruh tani perempuan terbilang rendah, hal ini tentu berpengaruh pada jenis pekerjaan yang dilakukan oleh buruh tani perempuan. Kegiatan buruh tani perempuan secara tidak langsung tidak berpengaruh oleh tingkat pendidikan, karena untuk melakukan pekerjaannya tidak memerlukan suatu keahlian yang didapatkan dengan menempuh lembaga pendidikan. Hal ini juga didukung oleh penelitian yang dilakukan oleh Hermawati (2014) tentang Strategi Nafkah Rumah Tangga Buruh Perekebunan Desa Patengan, Kecamatan Pancabali Kabupaten Bandung yang menyatakan bahwa bekerja di perkebunan tidak memerlukan pendidikan tinggi dan jauh lebih produktif menjadi buruh untuk menopang kehidupan keluarga, hal itulah yang menyebabkan sebagian besar penduduk belum menyadari pentigngnya pendidikan.

Jumlah anggota keluarga buruh tani perempuan dengan kisaran 2-4 orang sebanyak 16 responden dengan persentase sebesar 53,3\%, kisaran 5-7 orang sebanyak 12 responden dengan persentase sebesar $40 \%$, dan $>7$ orang sebanyak 2 responden dengan persentase sebesar $6,7 \%$. Hal ini dapat dilihat bahwa jumlah anggota keluarga buruh tani perempuan terbanyak atau lebih dari setengah responden penelitian yakni 30 responden dari 16 respoden yang memiliki anggota keluarga ada pada kisaran antara $2-4$ orang dengan dengan persentase sebesar 53,3\%.

Lama bekerja di PT Anam Koto dengan $<1$ tahun sebanyak 4 responden dengan persetase sebesar 13,3\%, kisaran 1-2 tahun sebanyak 14 responden dengan persentase sebesar 46,7 \%, kisaran 3-4 tahun sebanyak 12 responden dengan persentase sebesar $40 \%$. Hal ini dapat dilihat bahwa lama bekerja di PT Anam Koto lebih banyak pada kisaran 1-2 tahun dengan persentase sebesar 46,7\% . Lama bekerja di PT Anam Koto merupakan salah satu syarat untuk menjadi buruh harian tetap. Selain lama bekerja syarat menjadi buruh 
harian tetap adalah kinerja yang baik dan rekomendasi dari mandor di lapangan. Status buruh harian lepas lebih mendominasi dari pada buruh harian tetap karena akses peralihan buruh harian lepas ke buruh harian tetap masih terbatas dalam porsi dan kriteria tertentu yang ditetapkan oleh perusahaan.

\section{Pola Kerja Buruh Tani Perempuan}

Pekerjaan buruh tani perempuan adalah melakukan pemeliharaan tanaman kelapa sawit, pemupukan, dan mengumpulkan brondolan kelapa sawit. Buruh tani perempuan bekerja enam hari selama satu minggu yaitu dari hari senin hingga sabtu, dan mempunyai hari libur yaitu hari minggu dan tanggal merah/hari libur nasional. Dengan rincian dapat terlihat pada Tabel.2

Tabel. 2 Rincian Waktu Kerja Buruh Tani di PT Anam Koto

\begin{tabular}{l}
\hline Waktu \\
\hline $07.00-07.30$ \\
\hline $07.30-09.30$ \\
\hline $09.30-10.00$ \\
\hline $10.00-11.30$ \\
\hline $11.30-12.30$ \\
\hline $12.30-15.00$ \\
\hline
\end{tabular}

\begin{tabular}{l}
\hline Kegiatan \\
\hline Apel pagi \\
\hline Kerja \\
\hline Istirahat \\
\hline Kerja \\
\hline Istirahat \\
\hline Kerja \\
\hline
\end{tabular}

Dari Tabel .2 dapat dilihat bahwa jam 07.00 - 07.30 WIB buruh tani perempuan sudah melakukan apel pagi. Kegiatan pada saat apel pagi yaitu, pengecekan kehadiran buruh tani dan pemberian arahan pekerjaan yang harus dilakukan pada hari itu. Dan juga pembagian pekerjaan yang harus dilakukan dan serta lokasi bekerja. Setelah selesai apel mereka bekerja sesuai dengan perintah pimpinan atau asisten kebun. Pada jam 07.30 - 09.30 WIB setelah selesai apel mereka bekerja sesuai arahan asisten kebun, dan pada jam 09.30-10.00

WIB mereka istirahat sejenak melepaskan letih. Pada jam 10.00 - 11.30 WIB mereka lanjut bekerja, dan pada saat bekerja mereka diawasi oleh seorang mandor. Mandor adalah bawahan dari asisten kebun yang bertugas untuk melakukan pengawasan terhadap pekerjaan yang dilakukan oleh buruh tani. Pada jam 11.30 - 12.30 WIB mereka istirahat untuk melakukan makan siang dan sholat bagi yang beragama Islam. Pada jam 12.30 15.00 WIB mereka lanjut bekerja lagi dan menyelesaikan pekerjaannya dan setelah itu sudah boleh pulang. Berarti dalam satu hari kerja buruh tani perempuan menghabiskan waktu 8 jam sehari dari pukul 07.00 - 15.00 WIB, buruh tani perempuan menggunakan waktunya untuk bekerja 6 jam dalam sehari dan untuk apel serta istirahat selama 2 jam dalam sehari.

Buruh tani perempuan yang bekerja di PT Anam Koto ada yang tinggal di barak tempat hunian para buruh yang telah di sediakan PT Anam Koto dan ada juga yang tinggal di rumah miliknya sendiri di luar lokasi PT Anam Koto. Buruh tani yang tinggal di barak adalah buruh tani yang tidak memiliki rumah sendiri sehingga PT Anam Koto telah menyediakan rumah khusus untuk tempat tinggal para buruh. Cara buruh tani perempuan pergi ke perkebunan kelapa sawit tempat mereka bekerja yaitu dengan sepeda motor karna jarak antar rumah atau barak tempat tinggal ke lokasi tempat bekerja cukup jauh.

Buruh tani perempuan ini adalah buruh harian lepas. Buruh harian lepas yang bekerja di PT Anam Koto adalah ibu rumah tangga. Sebagian besar suami dari buruh tani yang bekerja di PT Anam Koto juga buruh tani di PT Anam Koto. Buruh tani harian lepas akan mengalamai masa training selama 3 bulan sampai 6 bulan masa percobaan. Jika mereka lulus masa training dengan penilaian dari keuletan, kehadiran, kemahiran, dan kepatuhan maka akan di angkat menjadi buruh harian tetap. Tetapi masih banyak buruh harian lepas tersebut belum memenuhi persyaratan kelulusan sehingga mereka tetap menjadi buruh harian lepas. 
Buruh harian lepas adalah buruh yang diberi upah apabila mereka melakukan pekerjaan. Upah yang telah ditetapkan perusahaan dalam satu hari yaitu sebesar Rp 91.200. Mereka menerima upah sekali sebulan, yaitu setiap tanggal 10 di awal bulan. Upah yang mereka terima yaitu jumlah hari bekerja dikali Rp Rp 91.200. Menurut Pasal 1 angka 30

Undang-Undang Nomor 13 Tahun 2003 pengertian upah adalah hak pekerja/buruh yang diterima dan dinyatakan dalam bentuk uang sebagai imbalan dari pengusaha atau pembri kerja kepada pekerja/buruh yang ditetapkan dan dibayarkan menurut suatu perjanjian kerja, kesepakatan, atau perundang-undangan, termasuk tunjangan bagi pekerja/buruh dan keluarganya atas suatu pekerjaan dan/atau jasa yang telah atau akan dilakukan. Secara umum upah mempuyai kedudukan startegisnya, baik bagi pekerja keluarganya dan perusahaan maupun bagi kepentingan nasional. Bagi pekerja, upah diperlukan untuk membiayai hidup dirinya dan keluarganya serta sebagai motivasi untuk peningkatan produktivitas. Bagi perusahaan, upah merupakan salah satu komponen biaya produksi yang dipandang dapat mengurangi laba yang dihasilkan. Maka perusahaan berusaha untuk menekan upah tersebut sampai pada tingkat yang paling minimum sehingga laba perusahaan dapat ditingkatkan. Sedangkan bagi pemerintah, upah merupakan sarana pemerataan pendapatan dan peningkatan kesejahteraan.

\section{Pendapatan Buruh Tani Perempuan yang Bekerja di PT Anam Koto}

Pendapatan buruh tani perempuan di PT Anam Koto di peroleh dari hasil penerimaan yang diperoleh dari upah harian di kurangi biaya yang dikeluarkan pada saat bekerja. Tabel 3. Rata-Rata Pendapatan Buruh Tani Perempuan yang Bekerja di PT Anam Koto

\begin{tabular}{ll}
\hline No & Uraian \\
\hline 1 & Penerimaaan \\
\hline 2 & Biaya yang dikeluarkan \\
\hline & a. Pinjaman Koperasi \\
\hline & b. Transportasi \\
\hline c. Makan \\
\hline 3 & Pendapatan \\
\hline
\end{tabular}

\begin{tabular}{l}
\hline Rata-rata \\
\hline $\mathrm{Rp} \mathrm{1.501.760}$ \\
\hline $\mathrm{Rp} \mathrm{338.333}$ \\
\hline $\mathrm{Rp} 111.100$ \\
\hline $\mathrm{Rp} 249.467$ \\
\hline $\mathrm{Rp} 789.880$ \\
\hline
\end{tabular}

Dari Tabel.3 dapat dilihat bahwa rata-rata buruh tani perempuan memperoleh penerimaan sebesar Rp Rp 1.501.760. Penerimaan merupakan hasil perkalian dari upah harian dengan jumlah hari bekerja dalam sebulan. Pemberian upah harian yang mereka terima yaitu Rp 91.200/hari.Besarnya penerimaan yang diperoleh pada masing-masing buruh tani perempuan berbeda. Hal ini dipengaruhi oleh jumlah hari mereka bekerja dalam satu bulan. Pemberian Upah dilakukan sekali sebulan yaitu pada tanggal 10 setiap bulannya.

Biaya yang dikeluarkan saat bekerja di PT Anam Koto meliputi pinjaman koperasi, biaya transportasi, dan biaya makan. Rata-rata pinjaman koperasi buruh tani perempuan yang bekerja di PT Anam Koto adalah Rp 338.333. Pinjaman koperasi berupa alat-alat yang diambil untuk keperluan bekerja seperti tangki semprot, apround, masker, sarung tangan, kaca mata, sepatu boot. Pinjaman koperasi harus dibayar setiap bulannya dan langsung di potong pada saat penerimaan upah.

Biaya transportasi adalah biaya yang dikeluarkan untuk membeli bahan bakar minyak kendaraan buruh tani perempuan untuk pergi ke perkebunan tempat mereka bekerja. Biaya transportasi yang digunakan tergantung jauh dekatnya lokasi perkebunan tempat mereka bekerja. Rata-rata biaya transportasi buruh tani perempuan adalah $\mathrm{Rp}$ 111.100.

Biaya makan adalah biaya yang dikeluarkan untuk membeli makan untuk mengisi energi buruh tani perempuan saat bekerja. Rata-rata biaya makan buruh tani perempuan 
adalah $\mathrm{Rp} \operatorname{Rp} 249.467$. Biaya makan yang dihitung adalah makan pagi dan siang yaitu pada pagi hari saat memulai bekerja dan siang pada saat istirahat siang.

Rata-rata pendapatan yang diterima buruh tani perempuan yang bekerja di PT Anam Koto adalah $\mathrm{Rp}$ 789.880. Pendapatan merupakan hasil penerimaan yang dikurangi biayabiaya yang dikeluarkan pada saat bekerja, seperti pinjaman koperasi, biaya transportasi, dan biaya makan. Menurut Peraturan Pemerintah (PP) Nomor 78 Tahun 2015 tentang Pengupahan, UMP Sumatera Barat adalah Rp 2.289.228. Dilihat dari pendapatan yang di peroleh buruh harian lepas yang bekerja di PT Anam Koto yang memiliki rata-rata Rp 789.880 kurang dari UMP Sumatera Barat. Jika dibandingkan dengan hasil penelitiian Nidia Nindi Nati (2012) tentang Alokasi Waktu dan Peran Pendapatan Wanita Penyiang Lahan Gambir Dalam Pendapatan Keluarga di Kenagarian Talang Maur Kecamatan Mungka Kabupaten Lima Puluh Koto, pendapatan rata-rata yang diperoleh perempuan penyiang lahan gambir tersebut yaitu Rp 668.360, maka pendapatan buruh tani perempuan yang bekerja di PT Anam Koto lebih tinggi yaitu Rp 789.880 dari pada pendapatan wanita penyiang lahan gambir.

Tabel. 4 Pendapatan Buruh Tani Perempuan yang bekerja di PT Anam Koto

\begin{tabular}{ll}
\hline Pendapatan (Rp)(000) & Jumlah (Orang) \\
\hline$<500$ & 1 \\
\hline $500-1.000$ & 24 \\
\hline$>1.000-1.500$ & 4 \\
\hline$>1.500-2.000$ & 1 \\
\hline Jumlah & 30 \\
\hline
\end{tabular}

\begin{tabular}{l}
\hline Persetase (\%) \\
\hline 3,3 \\
\hline 80 \\
\hline 13,3 \\
\hline 3,3 \\
\hline 100 \\
\hline
\end{tabular}

Berdasarkan Tabel. 4 pendapatan buruh tani perempuan yang bekerja di PT Anam Koto selama satu bulan dengan pendapatan yang paling sedikit yaitu kurang dari $\mathrm{Rp}$ 500.000 sebanyak satu responden atau sebesar 3,3\%, sedangkan pendapatan paling banyak didapatkan oleh responden yaitu rentang Rp 500.000 sampai Rp 1.000 .000 sebanyak 24 responden atau sebesar 80\%, pendapatan besar dari Rp 1.000.000 sampai Rp 1.500 .000 sebanyak 4 responden atau sebesar $13,3 \%$, dan pendapatan besar dari Rp 1.500 .000 sampai Rp 2.000.000 sebanyak 1 responden atau sebesar 3,3\%.

\section{E. Alokasi Jam Kerja yang dimasuki Buruh Tani Perempuan yang Bekerja di PT Anam Koto}

Alokasi jam kerja yang dimasuki buruh tani perempuan berdasarkan kegiatan yang mereka lakukan di perkebunan. Berikut rincian alokasi jam kerja buruh tani perempuan.

Tabel. 5 Alokasi Jam Kerja yang dimasuki Buruh Tani Perempuan Selama Satu Bulan Januari 2019

\begin{tabular}{ll}
\hline Kegiatan & $\begin{array}{l}\text { Jumlah rata-rata jam kerja/individu pada } \\
\text { setiap kegiatan }\end{array}$ \\
\hline Semprot piringan dan pasar pikul & 24 Jam \\
\hline Semprot gawangan & 10,83 Jam \\
\hline Oles anak kayu & 6,4 Jam \\
\hline Babat & $9,8 \mathrm{Jam}$ \\
\hline Pemupukan & 8,8 Jam \\
\hline Pengutipan brondol & 32 Jam \\
\hline
\end{tabular}

Jumlah jam kerja rata-rata/individu yang dilakukan oleh buruh tani perempuan di PT Anam Koto pada setiap kegiatan memiliki perbedaan pada alokasi jam kerjanya. Pada 
kegiatan semprot piringan dan pasar pikul dengan jumlah alokasi jam kerja/individu selama satu bulan yang dilakukan oleh buruh tani perempuan yaitu sebesar 24 jam/bulan. Semprot piringan dan pasar pikul adalah pengendalian gulma di piringan kelapa sawit dan membersihkan akses jalan untuk mengeluarkan buah saat panen maupun pada saat perawatan.

Pada kegiatan semprot gawangan dengan jumlah alokasi jam kerja/individu selama satu bulan yang dilakukan oleh buruh tani perempuan yaitu sebesar 10,83 jam/bulan. Semprot gawangan adalah pengendalian semua jenis gulma yang berada digawangan seperti gulma berdaun lebar dan sempit.

Pada kegiatan Oles anak kayu dengan jumlah alokasi jam kerja/individu selama satu bulan yang dilakukan oleh buruh tani perempuan yaitu sebesar $6,4 \mathrm{jam} / \mathrm{bulan}$. Oles anak kayu adalah pencabutan anak kayu atau tanaman yang mampu bertahan akarnya untuk mencegah persaingan penyerapan unsur hara antara tanaman inti dengan gulma penganggu.

Pada kegiatan babat dengan jumlah alokasi jam kerja/individu selama satu bulan yang dilakukan oleh buruh tani perempuan yaitu sebesar 9,8 jam/bulan. Babat adalah rumput-rumput atau pakisan. Pembabatan dilakukan dengan cara menebas batang pohon atau gulma dengan menggunakan parang babat.

Pada kegiatan pemupukan dengan jumlah alokasi jam kerja/individu selama satu bulan yang dilakukan oleh buruh tani perempuan yaitu sebesar 8,8 jam/bulan. Pemupukan merupakan kegiatan memenuhi kebutuhan unsur hara bagi tanaman dengan optimal untuk berproduksi tinggi.

Pada kegiatan pengutipan brondol dengan jumlah alokasi jam kerja/individu selama satu bulan yang dilakukan oleh buruh tani perempuan yaitu sebesar $32 \mathrm{jam} / \mathrm{bulan}$.

Pengitipan brondol adalah kegiatan yang dilakukan untuk mengumpulkan sisa-sisa buah yang tinggal di sekitaran batang kelapa sawit.

Tabel 6. Rata-Rata Jam Kerja Buruh Tani Perempuan yang Bekerja di PT Anam Koto

\begin{tabular}{|c|c|c|}
\hline No & Uraian & Rata-rata (Jam) \\
\hline 1 & Rata-rata/hari & 5,57 \\
\hline 2 & Rata-rata/minggu & 22,96 \\
\hline 3 & Rata-rata/bulan & 91,83 \\
\hline
\end{tabular}

Menurut Elfindri (2004: 4 ) Jam kerja dibagi menjadi pemanfaatan jam sedikit atau sering disebut dengan diistilahkan sebagai setengah menganggur (labor underutilization) yakni bilamana seseorang bekerja antara 1 - 34 jam selama seminggu yang lalu. Dasar 34 jam sebagai batas adalah berdasarkan arbitrary secara beralasan tanpa dasar yang menyatakan bahwa bilamana seseorang bekerja antara $1-5$ jam perhari masih dikategorikan rendah. Pekerjaan normal ( normal utilization) bila seseorang bekerja antara $35-60$ jam selama seminggu yang lalu atau sekitar $6-8$ jam per hari. Sedangkan pekerja lebih (over utilization) bilamana melebihi bekerja 60 jam selama seminggu.

Pada buruh harian lepas yang bekerja di PT Anam Koto memiliki rata-rata jam kerja/hari yaitu 5,57 jam/hari, sedangkan untuk rata-rata jam kerja/minggu yaitu 22,96 jam/minggu dapat dikatakan bahwa buruh harian lepas tersebut adalah setengah menganggur atau pekerja tidak penuh, dan untuk rata-rata jam kerja/bulan yaitu 91,83 jam/bulan.

\section{KESIMPULAN}

\section{A. Kesimpulan}

Profil buruh tani perempuan yang bekerja di PT Anam Koto, rata-rata buruh tani perempuan memiliki usia yang produktif untuk bekerja, namun tidak memiliki latar belakang pendidikan yang tinggi, memiliki jumlah anggota keluarga paling banyak kisaran 
2-4 orang dan jumlah tanggungan keluarga paling banyak kisaran 1-3 orang dan lama bekerja di PT Anam Koto 1-2 tahun. Pola kerja buruh tani perempuan yang bekerja di PT Anam Koto yaitu mereka bekerja melakukan pemeliharaan kelapa sawit, pemupukan dan mengumpulkan brondolan kelapa sawit. Buruh tani perempuan bekerja enam hari selama satu minggu yaitu dari hari senin hingga sabtu, dan mempunyai hari libur yaitu hari minggu.. Buruh tani perempuan yang bekerja di PT Anam Koto ada yang tinggal di barak tempat hunian para buruh yang telah di sediakan PT Anam Koto dan ada juga yang tinggal di rumah miliknya sendiri di luar lokasi PT Anam Koto.

Pendapatan buruh tani perempuan yang bekerja di PT Anam Koto selama satu bulan dengan pendapatan paling banyak didapatkan oleh responden yaitu rentang $\mathrm{Rp} 500.000$ sampai Rp 1.000.000 sebanyak 24 responden atau sebesar 80\%. Jumlah jam kerja ratarata/individu yang dilakukan oleh buruh tani perempuan di PT Anam Koto pada setiap kegiatan memiliki perbedaan pada alokasi jam kerjanya. Pada kegiatan pengutipan brondol adalah kegiatan yang mempunyai waktu paling banyak dengan jumlah alokasi jam kerja/individu selama satu bulan yang dilakukan oleh buruh tani perempuan yaitu sebesar $32 \mathrm{jam} / \mathrm{bulan}$.

\section{B. Saran}

Dari profil buruh tani, tidak memiliki latar belakang pendidikan tinngi,sehingga mereka tidak punya pilihan lain untuk memilih pekerjaan yang lebih baik. Dan kebanyakan buruh tani perempuan banyak yang tidak mengikuti aturan K3 (Keselataman dan Kesehatan Kerja) perusahaan sehingga dapat membahayakan keselamatan kerja, dengan melihat waktu dalam melakukan pekerjaan di perkebunan kelapa sawit, sebaiknya buruh tani mematuhi peraturan yang telah ditetapkan oleh perusahan, agar dapat mengurangi kecelakaan kerja.

Dari pendapatan yang diperoleh buruh tani yang masih rendah, sebaiknya perusahaan mempertimbangkan lagi dalam besarnya upah yang diberikan kepada buruh tani.

\section{DAFTAR PUSTAKA}

Atiqoh, A. N. 2012. Analisis Curahan Tenaga Kerja dan Pendapatan Peternak Kambing di Kelompok Peternak Simpay Tampomas Kecamatan Cimalaka Sumedang (Studi Kasus di Kelompok Peterak Kambing Simpay Tampomas Kecamatan Cimalaka Sumedang). Skripsi Fakultas Peternakan IPB.Bogor.

Badan Pusat Statistik. 2017. Statistik Kelapa Sawit Indonesia 2017. Badan Pusat Statistik. Jakarta

Daniel, Moehar. 2003. Metode Penelitian Sosial Ekonomi. Jakarta : PT Bumi Aksara. 161 Hal.

Elfindri., dan Nasri Bachtiar. 2004. Ekonomi Ketenagakerjaan. Andalas University Press. Padang

Hermawati, Dian. 2014. Strategi Nafkah Rumah Tangga Buruh Perkebunan Desa Patengan, Kecamatan Pancabali, Kabupaten Bandung. Skripsi Fakultas Ekologi Manusia IPB. Bogor.

Ifitira. 2017. Strategi Nafkah Rumah Tangga di Desa Perkebunan (Kasus Perkebunan Kelapa Sawit di Dusun Kiarapandak, Kecamatan Sukajaya, Kabupaten Bogor, Jawa Tengah). Skripsi Fakultas Ekologi Manusia IPB. Bogor.

I Made Winartha. 2006. Metodologi Penelitian Kuantitatif dan Kualitatif. Yogyakarta : Gaha Ilmu.

Mulyadi. 2014. Alokasi Jam Kerja Perempuan dalam Sektor Produktif pada Rumah Tangga Petani Kako di Nagari Sikucur Kecamatan Koto Kampung Dalam Kabupaten Pariaman. Skripsi Fakultas Pertanian Unand. Padang

Nati, Nidia Nindi. 2012. Alokasi Waktu dan Peran Pendapatan Wanita Penyiang Lahan Gambir Dalam Pendapatan Keluarga di Kenagarian Talang, Matur Kecamatan Mungka Kabupaten Lima Puluh Kota..Skripsi Fakultas Pertanian Unand. Padang 
Ramli, Moh. 2014. Peranan Wanita Tani dalam Pembangunan Pertanian. http://fakultaspertaianunars.blogspot.com/. [15 November 2018]

Sulaksana, J., Dinar, D., \& Ispanji, R. K. 2014. Tenaga Kerja dan Kontribusinya Terhadap Pendapatan Rumah Tangga (Suatu Kasus Pada Industri Rumah Tangga

Emping Jagung di Desa Ciomas Kecamatan Sukahaji Kabupaten Majalengka). Agrivet Journal Vol 2, No. 2

Suryanawati. 2011. Analisis Alokasi Tenaga Kerja Kepala Keluarga sebagai Tenaga Harian Lepas Pada Perkebunan Kelapa Sawit di PTP. Mitra Ogan dan Usaha Tani Karet di Kecamatan Lubuk Batang Kabupaten Ogan Komering Ulu. Jurnal Agripita Vol 1, No.2 
